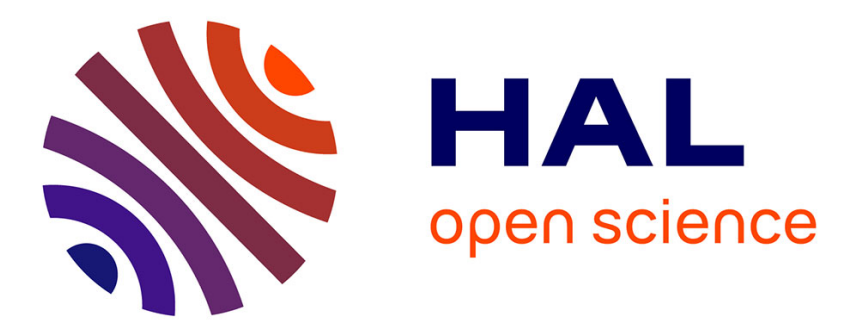

\title{
Rhenium-Catalyzed Reduction of Carboxylic Acids with Hydrosilanes
}

Duo Wei, Ruqaya Buhaibeh, Yves Canac, Jean-Baptiste Sortais

\section{To cite this version:}

Duo Wei, Ruqaya Buhaibeh, Yves Canac, Jean-Baptiste Sortais. Rhenium-Catalyzed Reduction of Carboxylic Acids with Hydrosilanes. Organic Letters, 2019, 21 (19), pp.7713-7716. 10.1021/acs.orglett.9b02449 . hal-02307033

\section{HAL Id: hal-02307033}

\section{https://hal-univ-rennes1.archives-ouvertes.fr/hal-02307033}

Submitted on 16 Dec 2019

HAL is a multi-disciplinary open access archive for the deposit and dissemination of scientific research documents, whether they are published or not. The documents may come from teaching and research institutions in France or abroad, or from public or private research centers.
L'archive ouverte pluridisciplinaire HAL, est destinée au dépôt et à la diffusion de documents scientifiques de niveau recherche, publiés ou non, émanant des établissements d'enseignement et de recherche français ou étrangers, des laboratoires publics ou privés. 


\title{
Rhenium-catalyzed reduction of carboxylic acids with hydrosilanes
}

\author{
Duo Wei, ${ }^{\mathrm{a}, \mathrm{b}}$ Ruqaya Buhaibeh, ${ }^{\mathrm{b}}$ Yves Canac $^{\mathrm{b}}$ and Jean-Baptiste Sortais ${ }^{\mathrm{b}, \mathrm{c} *}$ \\ ${ }^{\text {a }}$ Univ Rennes, CNRS, ISCR - UMR 6226, F-35000, Rennes, France \\ ${ }^{\mathrm{b}}$ LCC-CNRS, Université de Toulouse, CNRS, UPS, Toulouse, France \\ ${ }^{\mathrm{c}}$ Institut Universitaire de France, 1 rue Descartes, F-75231 Paris Cedex 05, France \\ Supporting Information Placeholder
}

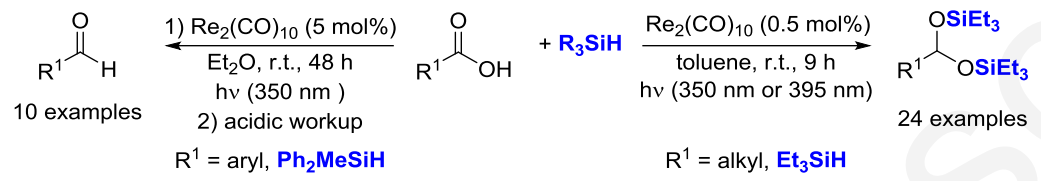

\begin{abstract}
Re}_{2}(\mathrm{CO})_{10}$ efficiently catalyzes the direct reduction of various carboxylic acids under mild conditions (r.t, irradiation 350 or $395 \mathrm{~nm}$ ). While aliphatic carboxylic acids were readily converted to the corresponding disilylacetals with low catalyst loading $(0.5 \mathrm{~mol} \%)$ in the presence of $\mathrm{Et}_{3} \mathrm{SiH}\left(2.2\right.$ equiv.), aromatic analogues required more drastic conditions $\left(\operatorname{Re}_{2}(\mathrm{CO})_{10} 5 \mathrm{~mol} \%\right.$, $\mathrm{Ph}_{2} \mathrm{MeSiH} 4.0$ equiv.) to afford the corresponding aldehydes after acid treatment.
\end{abstract}

Because of their essential role as organic synthons, simple and direct methods to produce aldehydes are highly required. The reduction of carboxylic acids, which is a common transformation, is one of the classical methods for the formation of aldehydes. However, due to the higher reactivity of aldehyde products with respect to acid precursors, the direct reduction of carboxylic acids to aldehydes is generally tedious and the formation of alcohols due to excessive reduction is difficult to avoid. ${ }^{1}$ As a main consequence, the preferred conventional route involves a two-step procedure implying complete reduction of acids to the corresponding alcohols, followed by oxidation of these to the desired aldehydes. ${ }^{2}$ An alternative method is to convert the carboxylic acids into more reactive derivatives (acyl halides, anhydrides or esters) before reducing them to aldehydes. ${ }^{3}$

In this general context, organosilanes offer an unique opportunity to reduce carboxylic acid derivatives with high chemoselectivity. ${ }^{4}$ In particular, silanes allow the direct reduction of carboxylic acids into protected aldehydes in the form of disilylacetals, the latter being then easily converted into aldehydes by acid treatment.

The first example of such transformation was reported by Nagashima et al., using ruthenium carbonyl catalysts in the presence of 1,2-bis(dimethylsilyl)benzene. ${ }^{5}$ From iron based catalysts we have developed a selective and switchable method to form either alcohols in the presence of phenylsilane under UV irradiation, or aldehydes with TMDS (1,1,3,3tetramethyldisiloxane) under thermal activation. ${ }^{6}$ In addition, the Brookhart group demonstrated that the borane $\mathrm{B}\left(\mathrm{C}_{6} \mathrm{~F}_{5}\right)_{3}$ acts as an effective catalyst for the reduction of aliphatic and aromatic carboxylic acids to disilylacetals in the presence of bulky tertiary silanes. ${ }^{7}$ Finally, we have recently shown that the complex $\mathrm{Mn}_{2}(\mathrm{CO})_{10}$ can catalyze the reduction of various carboxylic acids into stable disilylacetals under the influence of UV light irradiation $(350 \mathrm{~nm}) .^{8}$

Compared with manganese, ${ }^{9}$ its lighter analogue, whose applications in reduction catalysis are in constant progression, ${ }^{10}$ rhenium has been more rarely used in this field and in particular in hydrosilylation type-reactions. ${ }^{11}$ The first rheniumcatalyzed hydrosilylation was described by Toste in 2003 using the complex $\left[\left(\mathrm{PPh}_{3}\right)_{2} \operatorname{Re}(\mathrm{O})_{2} \mathrm{I}\right],{ }^{12}$ thus demonstrating the potential of high valent $\mathrm{Re}$ oxo complexes in such transformation. ${ }^{13}$ Ison and coll. reported also a series of low valent $\mathrm{Re}$ (III) complexes for the hydrosylation of aldehydes, while Berke demonstrated that readily available nitrosyl $\operatorname{Re}(\mathrm{I})$ complexes could be effective for the reduction of various carbonyl precursors. Finally, it has been mentioned that mono- and dinuclear $\operatorname{Re}(\mathrm{I})$ complexes such as $\operatorname{Re}(\mathrm{CO})_{5} \mathrm{Cl}$ and $\mathrm{Re}_{2}(\mathrm{CO})_{10}$ can behave as valuable catalysts in hydrosilylation reactions for carbonyl derivatives under photochemical activation. ${ }^{14}$ Inspired by this work and in line with our effort to develop catalysts based on group 7 transition metals, ${ }^{15}$ we report here after the first rhenium catalyzed reduction of carboxylic acids, being aliphatic or aromatic in nature, under either UV (350 $\mathrm{nm}$ ) or LED's (395 nm) irradiation, and under mild conditions.

The first conditions used here are based on those recently developed in the manganese series for the reduction of carboxylic acids. And thus by selecting the complex $\operatorname{Re}_{2}(\mathrm{CO})_{10}$ as pre-catalyst $(5 \mathrm{~mol} \%)$ and the tertiary silane $\mathrm{Et}_{3} \mathrm{SiH}$ (4 equiv.) as reducing agent, a full conversion of 2-naphthyl acetic acid $\mathbf{1 a}$ to the corresponding disilylacetal product $\mathbf{2 a}$ was observed after $3 \mathrm{~h}$ of irradiation at $395 \mathrm{~nm}$ (LED, $45 \mathrm{~W}$ ), at r.t. (ca. 30 ${ }^{\circ} \mathrm{C}$ ) in toluene (Table 1, entry 1). The conditions were further optimized to decrease both the catalytic charge to $0.5 \mathrm{~mol} \%$ (and even up to $0.2 \mathrm{~mol} \%$, entry 4 ) and the amount of $\mathrm{Et}_{3} \mathrm{SiH}$ to 2.2 equiv. (entries 5-6). After $9 \mathrm{~h}$ of irradiation, under these 
conditions $\left(\operatorname{Re}_{2}(\mathrm{CO})_{10} 0.5 \mathrm{~mol} \%, \mathrm{Et}_{3} \mathrm{SiH} 2.2\right.$ equiv.)), the desired product $\mathbf{2 a}$ was finally obtained with high conversion and selectivity (97\%, entry 6). The nature of the silane was shown to be crucial for the selectivity of the reaction (Table $\mathrm{S} 1$ ). Indeed, the use of $\mathrm{Et}_{2} \mathrm{SiH}_{2}$ and $\mathrm{PhSiH}_{3}$ (4 equiv., entries 1 and 3) lowered the conversion of $\mathbf{1 a}$, while $\mathrm{Ph}_{2} \mathrm{SiH}_{2}$ reversed the selectivity in favor of the silylether $\mathbf{3 a}$, obtained in $80 \%$ yield after $3 \mathrm{~h}$ of exposure time (entry 2). For its part, TMDS (4 equiv.) led to a full conversion of 1 a but as a 55/45 mixture of adducts $\mathbf{2 a}$ and 3a (entry 4). Among other tertiary silanes tested $\left(\mathrm{Me}_{2} \mathrm{PhSiH}, \mathrm{Ph}_{2} \mathrm{MeSiH}, \mathrm{Ph}_{3} \mathrm{SiH}\right.$ and, $(\mathrm{EtO})_{3} \mathrm{SiH}$, entries 5-9), only $\mathrm{Me}_{2} \mathrm{PhSiH}$ led to the formation of $\mathbf{2 a}$ with satisfying selectivity (entry 5, 91\%), albeit being less efficient than $\mathrm{Et}_{3} \mathrm{SiH}$ under optimized conditions (entry 6).

Following these results, a series of control experiment was then performed (entries 7-13). In the absence of any light, under thermal conditions, or even in the presence of visible light, no conversion of 1a was detected after 9h (entries 7-9). With $0.5 \mathrm{~mol} \%$ catalytic charge and 2.2 equiv. of $\mathrm{Et}_{3} \mathrm{SiH}$, the higher conversion of 1a (ca. 98\%) was observed when the reaction was performed under UV irradiations $(350 \mathrm{~nm})$ in a Rayonnet RPR100 apparatus (entry 10). Noteworthy, the use of a medium pressure UV mercury lamp $(150 \mathrm{~W})$ led to a $69 \%$ yield of $\mathbf{2 a + 3 a}$ after only 1 hour and with good selectivity (entry 11). Changing the $\operatorname{Re}_{2}(\mathrm{CO})_{10}$ catalyst to $\operatorname{Re}(\mathrm{CO})_{5} \mathrm{Br}(1.0$ mol\%) does not affect the outcome of the reaction, ${ }^{14}$ the disilylacetal $\mathbf{2 a}$ being formed in $95 \%$ yield under UV irradiation $(350 \mathrm{~nm})$ (entry 12). In the absence of any Re-based catalyst, no conversion of the 2-naphthyl acetic acid 1 a could be detected (entry 13). Finally, the addition of TEMPO was shown to inhibit the reaction (entry 14 and Scheme S1, SI). ${ }^{14,16}$

To gain some insights about the mechanism of this catalyzed reaction, kinetic monitoring was performed in the case of 2-phenyl acetic acid 1c. The latter confirmed thus the initial formation of a silyl ester intermediate prior to the final product, namely the disilylacetal 2c (see Table S2 and Fig. S3, SI). An 'On-Off" experiment (see Fig. S4, S.I.) confirmed also that continuous irradiation is mandatory for the reduction to proceed.

Table 1. Optimization of the parameters for the reduction of 2-naphthyl acetic acid $1 a^{a}$

\begin{tabular}{lllllll} 
& & & & \\
\hline
\end{tabular}

\begin{tabular}{|c|c|c|c|c|c|c|}
\hline $7^{b}$ & 0.5 & $\begin{array}{l}\mathrm{Et}_{3} \mathrm{SiH} \\
(2.2)\end{array}$ & 9 & 0 & - & - \\
\hline $8^{c}$ & 0.5 & $\begin{array}{l}\mathrm{Et}_{3} \mathrm{SiH} \\
(2.2)\end{array}$ & 9 & 0 & - & - \\
\hline $9^{d}$ & 0.5 & $\begin{array}{l}\mathrm{Et}_{3} \mathrm{SiH} \\
(2.2)\end{array}$ & 9 & 0 & - & - \\
\hline $10^{\mathrm{e}}$ & 0.5 & $\begin{array}{l}\mathrm{Et}_{3} \mathrm{SiH} \\
(2.2)\end{array}$ & 9 & $>98$ & 98 & 2 \\
\hline $11^{\mathrm{f}}$ & 0.5 & $\begin{array}{l}\mathrm{Et}_{3} \mathrm{SiH} \\
(2.2)\end{array}$ & 1 & 69 & 94 & 6 \\
\hline $12^{\mathrm{e}, \mathrm{g}}$ & 1 & $\begin{array}{l}\mathrm{Et}_{3} \mathrm{SiH} \\
(2.2)\end{array}$ & 9 & 95 & 95 & 5 \\
\hline $13^{\mathrm{e}}$ & 0 & $\begin{array}{l}\mathrm{Et}_{3} \mathrm{SiH} \\
(2.2)\end{array}$ & 9 & & & \\
\hline $14^{\mathrm{f}}$ & 1 & $\begin{array}{l}\mathrm{Et}_{3} \mathrm{SiH} \\
(2.2)\end{array}$ & 18 & 0 & - & - \\
\hline
\end{tabular}

a General conditions: In a Schlenk tube, $\operatorname{Re}_{2}(\mathrm{CO})_{10}$, toluene, the silane and 1a were added in that order. The reaction was stirred under irradiation $(395 \mathrm{~nm}, 45 \mathrm{~W})$ at r.t.. Conversion and selectivity were detected by ${ }^{1} \mathrm{H}$ NMR on the crude reaction mixture. ${ }^{b}$ in the dark; ${ }^{\mathrm{c}}$ visible light irradiation $(30 \mathrm{~W}) ;{ }^{\mathrm{d}}$ at $100{ }^{\circ} \mathrm{C}$, no irradiation; ${ }^{\mathrm{e}}$ under UV irradiations ( $350 \mathrm{~nm}$ ) in a Rayonet RPR100 apparatus; ${ }^{\mathrm{f}}$ under UV irradiation with a medium pressure lamp $(150 \mathrm{~W})^{\mathrm{g}}$ $\operatorname{Re}(\mathrm{CO})_{5} \mathrm{Br}(1 \mathrm{~mol} \%)$ as catalyst. ${ }^{\mathrm{f}}$ in the presence of TEMPO (1 equiv.)

With the optimized conditions in hand, i.e. $\operatorname{Re}_{2}(\mathrm{CO})_{10}(0.5$ $\mathrm{mol} \%$ ), $\mathrm{Et}_{3} \mathrm{SiH}$ (2.2 equiv.) under irradiation (395 or $350 \mathrm{~nm}$, Table 1, entries 6 and 14), the synthetic scope of this Recatalyzed reduction of carboxylic acids to disilylacetals was investigated. ${ }^{17}$ As shown in Scheme 1, 2-naphthyl acetic acid 1a, 1-naphthyl acetic acid 1b, 2-phenyl acetic acid 1c, methyl substituted 2-phenyl acetic acids 1d-f and 2-(4methoxyphenyl) acetic acid $\mathbf{1 h}$ were smoothly converted in the corresponding disilyl acetal products in good yields (up to $97 \%$ ), although the reaction was shown to be less effective in the case of the ortho-substituted acid $\mathbf{1 f}$ (ca. in $62 \%$ isolated yield). Sterically hindered acids such as 2-phenylbutanoic acid $1 \mathrm{~g}$ could be also reduced but with lower efficiency (ca. $22 \%$ ). The reaction is tolerant to amino, fluoro and chloro groups, as demonstrated with the formation of $2 \mathbf{i}$ in $75 \%$ yield without any evidence of silylamine species, and of products $\mathbf{2} \mathbf{j}$ and $\mathbf{2 k}$ bearing fluorine and chlorine atoms formed in $92 \%$ and $98 \%$ yield, respectively. On the opposite, 2-(4-bromophenyl)acetic acid $\mathbf{1 l}$ inhibited the reaction, and debromination of $\mathbf{1 1}$ was detected (c.a. 3\%). Interestingly, hetero-aromatic substituted acetic acids based on thiophene $\mathbf{1 m}$ and $1 H$-indole $\mathbf{1 n}$ rings were reduced affording related products $\mathbf{2 m}$ and $\mathbf{2 n}$ in $59 \%$ and $89 \%$ yield, respectively. Carboxylic acids with longer carbon chains (2o-2t) gave also the corresponding acetals in excellent yield up to $98 \%$. Notably, dicarboxylic acid $1 \mathbf{r}$ led to the reduction product $\mathbf{2 r}$ in $99 \%$ yield. The internal $\mathrm{C}=\mathrm{C}$ bond in precursors $1 \mathrm{~s}$ and $\mathbf{1 t}$ was not altered while the conjugated $\mathrm{C}=\mathrm{C}$ bond of cinnamic acid was fully reduced yielding the saturated product 2o. ${ }^{18}$ The latter was also formed by direct reduction of 3-phenylpropionic acid 10. The scope of the reaction was successfully extended to cyclohexane- $\mathbf{1 u}$ and cyclopentane $\mathbf{1 v}$ carboxylic acids. Corresponding products $\mathbf{2 u}$ and $2 \mathbf{v}$ were formed in good yield (ca. 90-91\%). It is worth mentioning that acetic and formic acids were also reactive in the current reaction, producing $\mathbf{2 w}$ and $\mathbf{2 x}$ in about $90 \%$ yield. Noteworthy, a series of substrates was not tolerated under the 
selected catalytic conditions, such as 2-pyridine carboxylic acid, mandelic acid and 4-nitrophenyl- acetic acid.

Scheme 1. Scope of the Re-catalyzed reduction of carboxylic acids $\mathbf{1}$ to disilylacetals $\mathbf{2}$

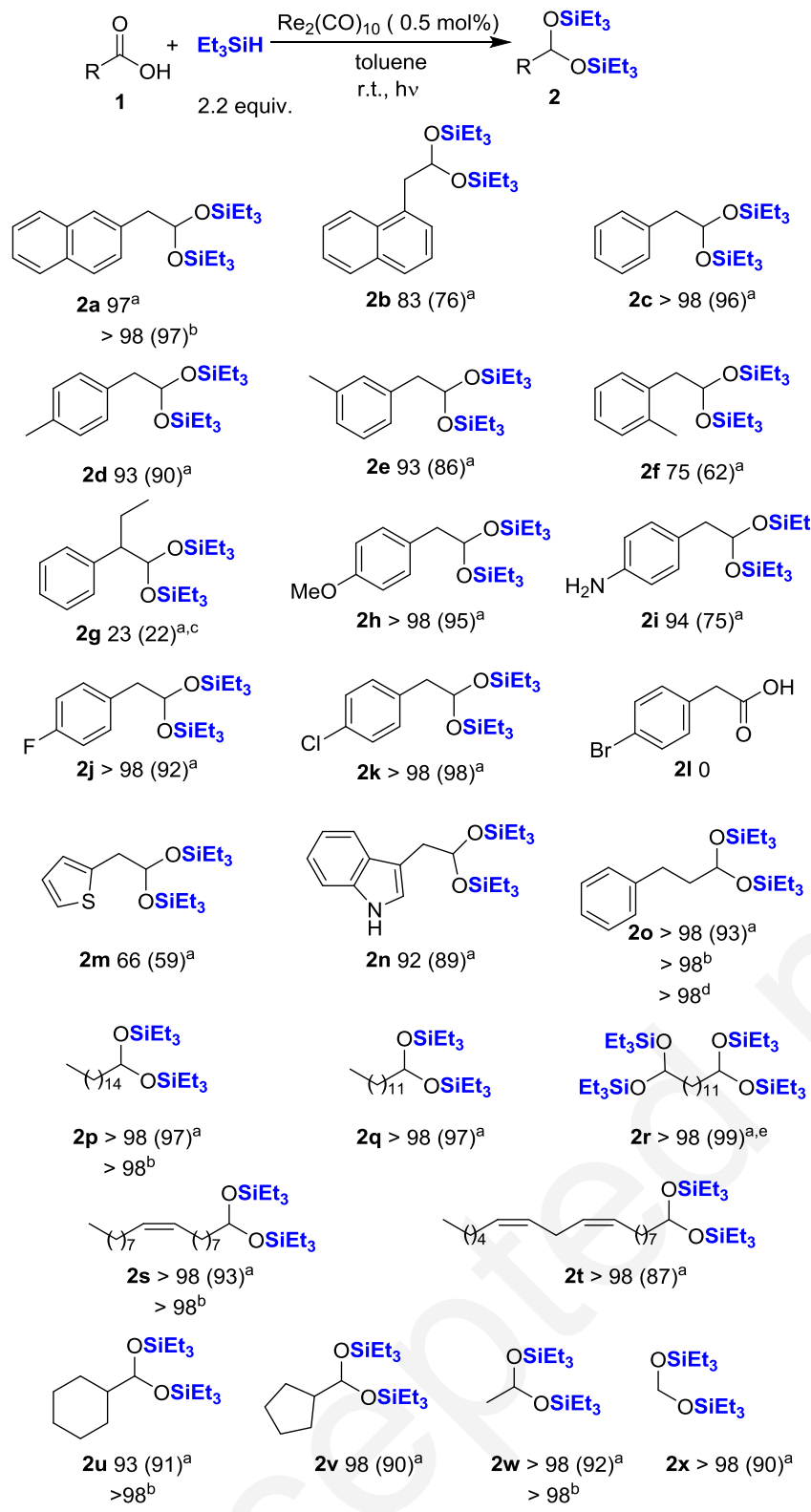

General conditions: carboxylic acid $(0.5 \mathrm{mmol}), \mathrm{Et}_{3} \mathrm{SiH}(176 \mu \mathrm{L}$, $1.1 \mathrm{mmol}, 2.2$ equiv.), $\operatorname{Re}_{2}(\mathrm{CO})_{10}(1.6 \mathrm{mg}, 0.5 \mathrm{~mol} \%)$, r.t., toluene $(1.0 \mathrm{~mL})$, irradiation, $9 \mathrm{~h}$; Conversion of $\mathbf{1}$ was detected by ${ }^{1} \mathrm{H}$ NMR of the crude mixture; and isolated yields of $\mathbf{2}$ were shown in parentheses; ${ }^{\mathrm{a}} \mathrm{UV}$ irradiation at $350 \mathrm{~nm}$ (Rayonet), ${ }^{\mathrm{b}}$ irradiation at $395 \mathrm{~nm}$ (LED), ${ }^{\mathrm{c}}$ NMR Yield, ${ }^{\mathrm{d}}$ starting from cinnamic acid, $\operatorname{Re}_{2}(\mathrm{CO})_{10}(1 \mathrm{~mol} \%), \mathrm{Et}_{3} \mathrm{SiH}$ (4.4 equiv.)

In the perspective of synthetic applications, a gram-scale experiment was performed from 3-phenylpropionic acid $10(1.0$ $\mathrm{g}, 6.7 \mathrm{mmol})$. After $24 \mathrm{~h}$ reaction, 10 was fully converted into the diacetal 20 along with the silylether 30 obtained in $72 \%$ and $28 \%$ NMR yield, respectively. After acid treatment $(1 \mathrm{~N}$ aqueous $\mathrm{HCl}), 5,8$ the related 3-phenylpropionaldehyde was finally isolated in $61 \%$ yield. ${ }^{19}$
Given the efficiency of the catalytic system, the reduction of more challenging benzoic acid derivatives was then investigated. Indeed, it has been reported that iron-based catalysts ${ }^{6}$ are not active in the reduction of aromatic acids while $\mathrm{Mn}_{2}(\mathrm{CO})_{10}{ }^{8}$ lead to low yields and that in the case of $\mathrm{B}\left(\mathrm{C}_{6} \mathrm{~F}_{5}\right)_{3}$, a higher catalytic charge compared to aliphatic acids is required. $^{7 \mathrm{a}}$

The first catalytic tests carried out under the conditions developed for the aliphatic acids did not lead to any reaction with benzoic acid 4a, even after $48 \mathrm{~h}$ (See Table S1 in S.I.). Increasing the catalyst loading $(5 \mathrm{~mol} \%)$ and the amount of $\mathrm{Et}_{3} \mathrm{SiH}$ (4 equiv.) enabled the formation of the corresponding benzaldehyde 5a as evidenced by ${ }^{1} \mathrm{H}$ NMR of the crude mixture ( $25 \%$ conversion). In order to improve the conversion of benzoic acid $\mathbf{4 a}$ into benzaldehyde $\mathbf{5 a}$, other silanes were then tested (Table S1). A satisfactory conversion $(71 \%)$ was obtained in the presence of $\mathrm{Ph}_{2} \mathrm{MeSiH}$ (4 equiv.) after $48 \mathrm{~h}$ under irradiation $(350 \mathrm{~nm})$ at r.t in $\mathrm{Et}_{2} \mathrm{O}$. The general scope of the present reaction is presented on Scheme 2. 2-Naphthoic acid 4b afforded the corresponding aldehyde $\mathbf{5 b}$ in $82 \%$ isolated yield. Aromatic acids $\mathbf{4 c - d}$ bearing electron donating -OMe and $-\mathrm{NMe}_{2}$ groups led to the related aldehydes $\mathbf{5 c - d}$ in good yields. Hetero-aromatic acids based on furane, thiophene and pyrrole rings $(\mathbf{4 f}-\mathbf{4 h})$ and 4-cyanobenzoic acid $\mathbf{4 e}$ gave also the corresponding aldehydes but with moderate yields (23-58\%). Low conversions were observed from acid precursors containing an electron-withdrawing group, such 4(trifluoromethyl)benzoic acid $\mathbf{4 i}$ and 4 -chlorobenzoic acid $\mathbf{4 j}$. No conversion was detected for $\mathbf{5 k}$.

Scheme 2. Scope of the reduction of aromatic carboxylic acids to aldehydes ${ }^{\mathrm{a}}$

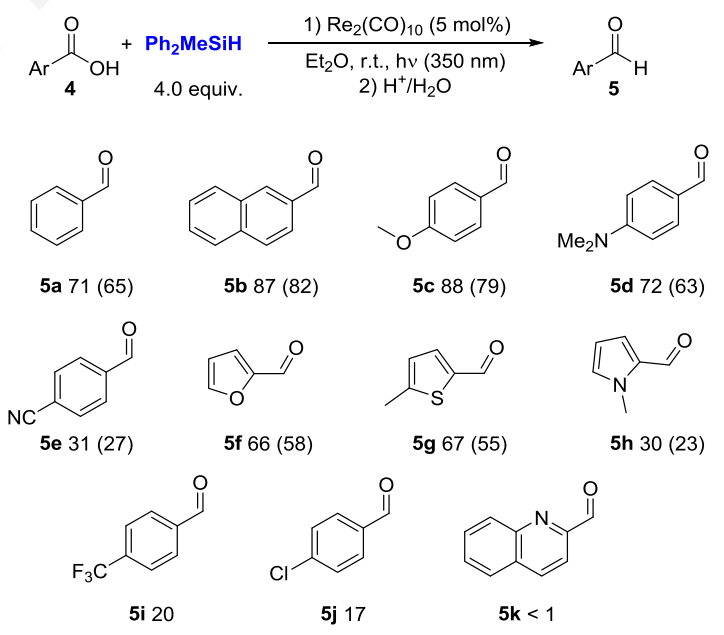

${ }^{\text {a }}$ General conditions: carboxylic acid $4(0.5 \mathrm{mmol}), \mathrm{Ph}_{2} \mathrm{MeSiH}$ (200 $\mu \mathrm{L}, 1.0 \mathrm{mmol}, 4.0$ equiv.), $\operatorname{Re}_{2}(\mathrm{CO})_{10}(8.2 \mathrm{mg}, 5.0 \mathrm{~mol} \%)$, r.t., $\mathrm{Et}_{2} \mathrm{O}(1.0 \mathrm{~mL})$, UV irradiation $\left.(350 \mathrm{~nm})\right), 48 \mathrm{~h}$, then hydrolysed at r.t. with trifluoroacetic acid $(99 \%, 0.25 \mathrm{~mL})$ for $3 \mathrm{~h}$. NMR-yield of 5 was detected by ${ }^{1} \mathrm{H}$ NMR of the crude mixture after hydrolysis, and isolated yields of $\mathbf{5}$ were shown in parentheses.

In conclusion, a variety of aliphatic and aromatic carboxylic acids were smoothly converted to the corresponding disilylacetals that could be easily converted into aldehydes by acidic treatment. Of notable achievements, compared to manganese catalyst $\mathrm{Mn}_{2}(\mathrm{CO})_{10}$, the catalyst loading of the present reaction with $\operatorname{Re}_{2}(\mathrm{CO})_{10}$ is lowered by a factor ten and the quantity of 
silanes halves. In addition, this new protocol was applied to a range of benzoic acids derivatives that are reluctant to be reduced by traditional methods.

\section{ASSOCIATED CONTENT}

\section{Supporting Information}

Details experimental procedures and characterization for all the products.

The Supporting Information is available free of charge on the ACS Publications website.

\section{AUTHOR INFORMATION}

\section{Corresponding Author}

* jean-baptiste.sortais@1cc-toulouse.fr

\section{Author Contributions}

The manuscript was written through contributions of all authors.

\section{Notes}

ORCID Duo Wei 0000-0002-5928-3151, Ruqaya Buhaibeh 00000003-1526-2946, Yves Canac 0000-0002-3747-554X, JeanBaptiste Sortais, 0000-0003-1178-8588.

\section{ACKNOWLEDGMENT}

We thank the Centre National de la Recherche Scientifique (CNRS), the Université de Rennes 1, the Université Toulouse III, Paul Sabatier, the Institut Universitaire de France (IUF) for general support of this project and Noël Lugan for his support. R. B. is grateful to the Embassy of Yemen in Paris, and the program Pause for financial support.

\section{REFERENCES}

1. (a) Cha, J. S.; Kim, J. E.; Lee, K. W., J. Org. Chem. 1987, 52, 5030-5032; (b) Cha, J. S.; Kim, J. E.; Oh, S. Y., Bull. Korean Chem. Soc. 1987, 8, 313-318; (c) Yokoyama, T.; Yamagata, N., Appl. Catal. A 2001, 221, 227-239; (d) Bedenbaugh, A. O.; Bedenbaugh, J. H.; Bergin, W. A.; Adkins, J. D., J. Am. Chem. Soc. 1970, 92, 5774-5775; (e) Muraki, M.; Mukaiyama, T., Chem. Lett. 1974, 3, 1447-1450; (f) Hubert, T. D.; Eyman, D. P.; Wiemer, D. F., J. Org. Chem. 1984, 49, 2279-2281; (g) Cha, J. S.; Lee, K. D.; Kwon, O. O.; Kim, J. M.; Lee, H. S., Bull. Korean Chem. Soc. 1995, 16, 561-565; (h) Brown, H. C.; Cha, J. S.; Nazer, B.; Yoon, N. M., J. Am. Chem. Soc. 1984, 106, 8001-8002; (i) Brown, H. C.; Cha, J. S.; Yoon, N. M.; Nazer, B., J. Org. Chem. 1987, 52, 5400-5406; (j) Marlett, E. M.; Park, W. S., J. Org. Chem. 1990, 55, 2968-2969; (k) Sato, F.; Jinbo, T.; Sato, M., Synthesis 1981, 1981, 871-871; (1) Corriu, R. J. P.; Lanneau, G. F.; Perrot, M., Tetrahedron Lett. 1987, 28, 3941-3944.

2. Trost, B. M., Comprehensive Organic Synthesis. Pergamon: Oxford, 1991; Vol. 8, pp 259-305.

3. (a) Zhang, M.; Li, N.; Tao, X.; Ruzi, R.; Yu, S.; Zhu, C., Chem. Commun. 2017, 53, 10228-10231; (b) Sakai, N.; Minato, K.; Ogiwara, Y., Tetrahedron Lett. 2017, 58, 4563-4567; (c) Tokuyama, H.; Yokoshima, S.; Yamashita, T.; Shao-Cheng, L.; Leping, L.; Fukuyama, T., J. Braz. Chem. Soc. 1998, 9, 381-387; (d) Braden, R.; Himmler, T., J. Organomet. Chem. 1989, 367, C12-C14; (e) Fukuyama, T.; Lin, S. C.; Li, L., J. Am. Chem. Soc. 1990, 112, 70507051; (f) Four, P.; Guibe, F., J. Org. Chem. 1981, 46, 4439-4445; (g) Ho, P. T.; Ngu, K. Y., J. Org. Chem. 1993, 58, 2313-2316; (h) Chandrasekhar, S.; Kumar, M. S.; Muralidhar, B., Tetrahedron Lett. 1998, 39, 909-910; (i) Kangani, C. O.; Kelley, D. E.; Day, B. W., Tetrahedron Lett. 2006, 47, 6289-6292; (j) Gutsulyak, D. V.; Nikonov, G. I., Adv. Synth. Catal. 2012, 354, 607; (k) Fujisawa, T.; Mori, T.; Tsuge, S.; Sato, T., Tetrahedron Lett. 1983, 24, 1543-1546; (1) Nagayama, K.; Shimizu, I.; Yamamoto, A., Bull. Chem. Soc. Jap.
2001, 74, 1803-1815; (m) Gooßen, L. J.; Ghosh, K., Chem. Commun. 2002, 836-837; (n) Gooßen, L. J.; Khan, B. A.; Fett, T.; Treu, M., Adv. Synth. Catal. 2010, 352, 2166-2170; (o) Fujihara, T.; Cong, C.; Terao, J.; Tsuji, Y., Adv. Synth. Catal. 2013, 355, 3420-3424.

4. Addis, D.; Das, S.; Junge, K.; Beller, M., Angew. Chem. Int. Ed. 2011, 50, 6004-6011.

5. Miyamoto, K.; Motoyama, Y.; Nagashima, H., Chem. Lett. 2012, 41, 229-231.

6. Misal Castro, L. C.; Li, H.; Sortais, J.-B.; Darcel, C., Chem. Commun. 2012, 48, 10514-10516.

7. (a) Bézier, D.; Park, S.; Brookhart, M., Org. Lett. 2013, 15, 496499; (b) Feghali, E.; Jacquet, O.; Thuéry, P.; Cantat, T., Catal. Sci. Technol. 2014, 4, 2230-2234.

8. Zheng, J.; Chevance, S.; Darcel, C.; Sortais, J.-B., Chem. Commun. 2013, 49, 10010-10012.

9. (a) Wang, C.; Yang, X., Chem. Asian J. 2018, 13, 2307-2315; (b) Trovitch, R. J., Acc. Chem. Res. 2017, 50, 2842-2852; (c) Trovitch, R. J., Synlett 2014, 25, 1638-1642; (d) Royo, B., Recent advances in catalytic hydrosilylation of carbonyl groups mediated by well-defined first-row late transition metals. In Advances in Organometallic Chemistry, Academic Press: 2019.

10. Kallmeier, F.; Kempe, R., Angew. Chem. Int. Ed. 2018, 57, 4660.

11. (a) Harms, R. G.; Herrmann, W. A.; Kühn, F. E., Coord. Chem. Rev. 2015, 296, 1-23; (b) Kuninobu, Y.; Takai, K., Chem. Rev. 2011, $111,1938-1953$.

12. (a) Kennedy-Smith, J. J.; Nolin, K. A.; Gunterman, H. P.; Toste, F. D., J. Am. Chem. Soc. 2003, 125, 4056-4057; (b) Nolin, K. A.; Krumper, J. R.; Pluth, M. D.; Bergman, R. G.; Toste, F. D., J. Am. Chem. Soc. 2007, 129, 14684-14696; (c) Nolin, K. A.; Ahn, R. W.; Toste, F. D., J. Am. Chem. Soc. 2005, 127, 12462-12463; (d) Nolin, K. A.; Krumper, J. R.; Pluth, M. D.; Bergman, R. G.; Toste, F. D., J. Am. Chem. Soc. 2007, 129, 14684-14696; (e) Nolin, K. A.; Ahn, R. W.; Kobayashi, Y.; Kennedy-Smith, J. J.; Toste, F. D., Chem. Eur. J. 2010, 16, 9555-9562.

13. (a) Ison, E. A.; Trivedi, E. R.; Corbin, R. A.; Abu-Omar, M. M., J. Am. Chem. Soc. 2005, 127, 15374-15375; (b) Du, G.; AbuOmar, M. M., Organometallics 2006, 25, 4920-4923; (c) Ison, E. A.; Cessarich, J. E.; Du, G.; Fanwick, P. E.; Abu-Omar, M. M., Inorg. Chem. 2006, 45, 2385-2387; (d) Du, G.; Fanwick, P. E.; Abu-Omar, M. M., J. Am. Chem. Soc. 2007, 129, 5180-5187; (e) Du, G.; AbuOmar, M. M., Curr. Org. Chem. 2008, 12, 1185-1198; (f) Du, G.; Fanwick, P. E.; Abu-Omar, M. M., Inorg. Chim. Acta 2008, 361, 3184-3192; (g) Royo, B.; Romão, C. C., J. Mol. Catal. A: Chem. 2005, 236, 107-112.

14. Toh, C. K.; Sum, Y. N.; Fong, W. K.; Ang, S. G.; Fan, W. Y., Organometallics 2012, 31, 3880-3887.

15. (a) Wei, D.; Roisnel, T.; Darcel, C.; Clot, E.; Sortais, J.-B., ChemCatChem 2017, 9, 80-83; (b) Li, H.; Wei, D.; Bruneau-Voisine, A.; Ducamp, M.; Henrion, M.; Roisnel, T.; Dorcet, V.; Darcel, C.; Carpentier, J.-F.; Soulé, J.-F.; Sortais, J.-B., Organometallics 2018, 37, 1271-1279; (c) Wei, D.; Sadek, O.; Dorcet, V.; Roisnel, T.; Darcel, C.; Gras, E.; Clot, E.; Sortais, J.-B., J. Catal. 2018, 366, 300309; (d) Zheng, J.; Elangovan, S.; Valyaev, D. A.; Brousses, R.; César, V.; Sortais, J.-B.; Darcel, C.; Lugan, N.; Lavigne, G., Adv. Synth. Catal. 2014, 356, 1093-1097; (e) Valyaev, D. A.; Wei, D.; Elangovan, S.; Cavailles, M.; Dorcet, V.; Sortais, J.-B.; Darcel, C.; Lugan, N., Organometallics 2016, 35, 4090-4098.

16. Tehfe, M.-A.; Lalevée, J.; Gigmes, D.; Fouassier, J. P., J. Polym. Sci., Part A: Polym. Chem. 2010, 48, 1830-1837.

17. In all cases, the selectivity $2: 3$ was above $94: 6$.

18. The reduction of crotonic (1y) and 3-methylcrotonic (1z) acids led after hydrolysis to butanal (5y) and 3-methylbutanal (5z) in $82 \%$ and $91 \%$ yield respectively, see S.I.

19. Liquid 3-phenylpropionaldehyde slowly evolved towards solid 2,4,6-tri(2-phenylethyl)-1,3,5-trioxane after purification. 